PEMBELAJAR: Jurnal Ilmu Pendidikan, Keguruan, dan Pembelajaran

Volume 1 Nomor 2 Oktober 2017

e-ISSN: 2549-9114 dan p-ISSN: 2549-9203

(Received: Agustus-2017; Reviewed: September-2017; Published: Oktober-2017)

\title{
Pengaruh Metode Bermain Peran Terhadap Kemampuan Komunikasi (Bahasa Ekspresif) Anak Taman Kanak-Kanak Raudhatul Athfal Alauddin Makassar
}

\author{
Nur Alim Amri \\ Dosen Pendidikan Guru Pendidikan Anak Usia Dini \\ Universitas Muhammadiyah Makassar \\ Corresponding e-mail: nuralim.amri17@gmail.com
}

\begin{abstract}
Abstrak:Kemampuan komunikasi merupakan bentuk pengembangan yang menitikberatkan pada aspek bahasa. Penelitian ini bertujuan untuk memperoleh data tentang gambaran penggunaan metode bermain peran, gambaran kemampuan komunikasi (Bahasa ekspresif) anak, serta untuk menguji apakah terdapat pengaruh metode bermain peran terhadap kemampuan bahasa ekspresif anak. Dengan melibatkan 20 orang anak didik yang dipilih dengan menggunakan teknik simple random sampling, data dikumpulkan melalui tes awal dan tes akhir setelah anak didik diberi perlakuan dengan menggunakan metode bermain peran yang kemudian data tersebut dianalisis melalui statistik deskriptif dan inferensial dalam bentuk uji Wilcoxon. Hasil analisis data menunjukkan bahwa kemampuan bahasa ekspresif anak mengalami peningkatan setelah diberi perlakuan melalui pembelajaran metode bermain peran.
\end{abstract}

Kata Kunci: kemampuan komunikasi; bahasa ekspresif; bermain peran

\begin{abstract}
Communication ability is a form of development that focuses on the language aspect. This study aims to obtain data about the description of the use of role playing methods, description of communication skills (expressive language) of children, as well as to test whether there is influence of role playing methods on the ability of expressive language children. By involving 20 students selected by simple random sampling technique, data were collected through initial and final test after the students were treated using role playing method then the data was analyzed through descriptive and inferential statistic in the form of Wilcoxon test. The results of data analysis showed that the expressive language ability of children increased after being treated through learning role play method.
\end{abstract}

Keywords: communication skills; expressive language; role playing

(7) (8) (C) 2017 -Pembelajar Universitas Negeri Makassar.Ini adalah artikel dengan akses terbuka di bawah licenci CC BY-NC-4.0 (https://creativecommons.org/licenses/by-nc/4.0/) 


\section{PENDAHULUAN}

Pada awal kelahiran, anak telah berkomunikasi. Melalui tangisan bayi mangutarakan keinginannya. Seiring dengan makin bertambahnya usia anak maka makin luas pula hubungan yang akan dijangkau oleh anak sehingga anak harus memiliki kemampuan berkomunikasi yang baik. Ciri khas pembelajaran Pestalozzi (Hartati, 2005:40-41) yang menitikberatkan pembelajaran hanya pada tiga kategori pengembangan kemampuan yaitu suara, bentuk dan bilangan. Dalam kategori pengembangan suara anak harus mendapatkan stimulus dan rangsangan untuk pengembangan kosakata karena Pestalozzi beranggapan perbendaharaan kosakata anak akan menyentuh berbagai dimensi keterampilan seperti keterampilan berkomunikasi.

Faktor utama lambatnya perkembangan kemampuan komunikasi terkhusus pada aspek kemampuan bahasa ekspresif anak disebabkan oleh rasa percaya diri yang rendah dikarenakan kurangnya stimulus lingkungan terhadap pengembangan kosakata anak, sehingga untuk dapat melakukan kegiatan komunikasi dengan menggunakan kata dan struktur kalimat yang baik serta menyampaikan pesan yang jelas, anak masih mengalami kesulitan. Syaiful mengungkapkan (2004:43) bahwa, "proses komunikasi dapat berlangsung dengan baik bila penerima pesan dapat menafsirkan secara tepat pesan yang disampaikan oleh komunikator melalui penggunaan bahasa dalam bentuk kata-kata atau kalimat".

Melalui metode pembelajaran bermain peran, anak dilatih untuk mengungkapkan ide, harapan, dan keinginan mereka sesuai imajinasi dengan batasan cerita atau peran yang diberikan. Metode bermain peran juga memberikan suasana baru bagi anak didik dalam proses pembelajaran yang dilakukan dalam suasana bermain tanpa terbebani oleh tugas perkembangannya. Moeslichatoen (2004:32) menekankan bahwa, "melalui kegiatan bermain peran anak dapat melatih kemampuan bahasanya dengan cara mendengarkan bunyi, mengucapkan suku kata, memperluas kosa kata serta berbicara sesuai dengan tata bahasa Indonesia".

Berdasarkan hal tersebut di atas, masalah yang akan dikaji dalam penelitian ini adalah "bagaimanakah gambaran penggunaan metode bermain peran dan apakah terdapat pengaruh bermain peran terhadap kemampuan bahasa ekspresif anak di Taman Kanak-kanak Raudhatul Athfal Alauddin Makassar”.

Hasil penelitian ini diharapkan memberi manfaat yang berarti baik secara teoretis maupun secara praktis. Dalam hal manfaat teoretis diharapkan dapat memberikan sumbangsih minimal memberikan penguatan tentang teori aplikasi metode bermain peran (role playing) terhadap kemampuan bahasa ekspresif anak. Manfaat secara praktis diharapkan berguna sebagai informasi bagi guru dan orang tua anak dalam upaya memperbaiki kemampuan aspek bahasa ekspresif anak di Taman Kanak-kanak Raudhatul Athfal Alauddin Makassar. Bagi peneliti, hasil penelitian ini dapat dijadikan sebagai temuan awal untuk melakukan penelitian lanjut mengenai pengembangan kemampuan komunikasi anak usia dini.

Berdasarkan pada hasil penelitian Benyamin S. Bloom bahwa pada usia 4 tahun anak dapat mencapai kapabilitas kecerdasannya hingga $50 \%$. Peningkatan sebesar $30 \%$ terjadi ketika anak mencapai usia 8 tahun. Artinya, $80 \%$ kapabilitas kecerdasan dapat diperoleh anak sejak usia dini. Apabila anak menjalani usia tersebut tanpa memperoleh rangsangan baik secara visual maupun verbal maka perkembangan otak anak $20 \%$ sampai $30 \%$ lebih kecil dari ukuran normal anak seusianya. Seperti yang dijelaskan oleh Mutiah (2010:5) bahwa, "selama tahun-tahun pertama otak bayi berkembang sangat pesat di mana menghasilkan bertriliun-triliun sambungan antarsel. Sambungan antarsel akan sangat kuat apabila diberikan stimulus (rangsangan) dan semakin sering digunakan". Dalam mengembangkan potensi-potensi yang ada pada diri anak berbagai cara dapat dilakukan seperti melalui visual, auditorial, dan kinestetik. Melalui cara visual anak dapat memahami warna, ruang, potret, atau gambar. Dengan cara auditorial anak belajar tentang jenis-jenis bunyi, suara atau kata-kata berirama, seperti musik, lagu, dan puisi. Melalui penerapan kinestetik anak melakukan berbagai gerakan seperti gerakan kenyamanan fisik, atau permainan-permainan. Melalui kinestetik pula anak belajar dapat memahami berbagai jenis emosi (Hartati, 2005:54). 
Untuk mencapai tahap perkembangan yang optimal pada anak, berbagai metode pembelajaran dapat ditempuh yang sesuai dengan jenis perkembangan yang ingin dicapai seperti motorik, kognitif, bahasa, kreativitas, emosi, dan sosial. Moeslichatoen (2004:19) mengungkapkan bahwa, "pemilihan metode harus sesuai dengan tujuan kegiatan". Untuk meningkatkan kemampuan kognitif dapat dilakukan melalui kegiatan-kegiatan yang bersifat eksploratif di mana kegiatan tersebut memungkinkan anak melakukan proses asimilasi dan akomodasi. Pada keterampilan motorik terdapat dua macam yaitu motorik halus dan motorik kasar. Keterampilan motorik halus dapat dikembangkan melalui kegiatan menggambar, origami, membentuk dengan menggunakan plastisin. Sedangkan keterampilan motorik kasar dapat dikembangkan melalui kegiatan bermain bola di mana anak akan melakukan aktivitas menangkap, menendang, dan berlari. Untuk membantu anak mengembangkan kemampuan kreativitasnya Santrock mengajak anak untuk terlibat dalam brainstorming, yaitu suatu teknik di mana anak diajak terlibat untuk memunculkan ide-ide kreatif yang baru dalam sebuah kelompok, menyoroti ide-ide orang lain, dan menyatakan secara praktis apapun yang muncul dalam pikiran. Pemberian rangsangan-rangsangan dalam bentuk bunyi-bunyian, membacakan cerita, puisi, bermain kartu huruf atau kata merupakan bagian dari beberapa kegiatan yang dapat dilakukan guna meningkatkan kemampuan bahasa anak. Hetherington (dalam Moeslichatoen, 2004:18) mengatakan, "akselerasi perkembangan bahasa anak terjadi sebagai hasil perkembangan fungsi simbolis".

Keterampilan dan potensi-potensi yang dimiliki oleh anak dapat dikembangkan melalui metode-metode pembelajaran yang cocok seperti metode bermain peran, metode karyawisata, metode bercakap-cakap, metode demonstrasi, metode proyek, metode bercerita, dan metode pemberian tugas. Dari beberapa metode pembelajaran yang dapat digunakan untuk mengembangkan kemampuan komunikasi anak seperti metode bermain peran, bercakap-cakap, dan metode bercerita. Dari ketiga metode tersebut, metode bercakapcakap dan metode bercerita lebih sering digunakan disetiap Taman Kanak-kanak dikarenakan metode tersebut lebih mudah daripada metode bermain peran. Dalam bermain peran, menonjolkan sisi pembelajaran menyelesaikan masalah melalui peragaan, identifikasi masalah, pemeranan, serta diskusi. Sehingga dalam prosesnya, bermain peran memiliki keunggulan daripada metode yang lain di mana dalam proses pembelajaran ini dimungkinkan peserta akan menciptakan analogi mengenai situasi kehidupan nyata dan terhadap analogi yang diwujudkan dalam bermain peran para peserta didik dapat menampilkan respon emosional dalam artian anak juga mampu mengenali dan memperagakan jenis-jenis emosi dalam mengkomunikasikan perasaan mereka. Metode bermain peran Depdiknas, (2005:13) "adalah cara memberikan pengalaman kepada anak melalui bermain peran, yakni anak diminta memainkan peran tertentu dalam suatu permainan peran". Misalnya, bermain jual beli sayur, bermain menolong anak jatuh, bermain menyayangi keluarga, dan lain-lain. Yang terpenting juga melalui bermain peran anak belajar cara bergaul yang baik melalui karakter tokoh baik, melibatkan komunikasi verbal dan interaksi nonverbal sehingga membantu perkembangan bahasa melalui proses memberi dan menerima pesan yang konsisten.

Anak-anak yang sedang berkomunikasi dengan teman sebayanya sebenarnya mereka sedang mencoba untuk berinteraksi dan dalam proses ini anak mempelajari bahasa dari kemampuan mereka memahami dan mendengarkan yang merupakan awal dari sebuah proses sosial. Seperti yang diungkapkan oleh Rakhmat (2009:9) yang menyatakan bahwa "komunikasi adalah peristiwa sosial-peristiwa yang terjadi ketika manusia berintegrasi dengan manusia lainnya". Menurut Raymond Ross (dalam Efendy, 2010) mengatakan bahwa "komunikasi adalah proses menyortir, memilih, dan pengiriman simbol-simbol sedemikian rupa agar membantu pendengar membangkitkan respon/ makna dari pemikiran serupa dengan yang dimaksudkan oleh pemberi pesan". Perkembangan bahasa anak bergerak cepat di usia satu sampai dua tahun. Hal ini dikarenakan kemampuan anak dalam meniru, mencontoh intonasi serta gestur orang dewasa di sekitarnya yang menggunakan bahasa. Pada akhir umur ketiga, anak-anak sudah dapat menggunakan lebih dari 1000 
kata. Pada masa kanak-kanak awal ini, perkembangan bahasa anak lebih dikenal dengan tahapan kombinasi tiga-empat-lima kata. Sehingga, perubahan kalimat-kalimat sederhana menjadi kalimat-kalimat yang kompleks terjadi pada anak usia dua sampai tiga tahun dan terus berlanjut hingga sekolah dasar (Bloom dalam Santrok, 2007: 360). Ketika menginjak usia empat hingga lima tahun, pembendaharaan kata anak mencapai 3.000 kata bahkan lebih. Dengan jumlah tersebut memungkinkan anak mulai mampu untuk bercerita tentang lingkungan sekitarnya.

Dengan kemampuan bahasa yang dimiliki oleh anak yang berkembang dengan cepat, mereka dapat berkomunikasi dengan orang lain, mengekspresikan diri mereka serta secara tidak langsung kosa kata mereka akan terus bertambah. Dengan pembiasaan dan pelatihan berbahasa yang bervariasi anak akan memiliki keterampilan berkomunikasi dengan baik. Hurlock (1987:176) menekankan bahwa komunikasi yang paling efektif dilakukan adalah dengan berbicara. Oleh karena itu, untuk mengetahui kemampuan komunikasi anak maka dapat dilihat dari perkembangan bahasa anak.

\section{METODE PENELITIAN}

Metode eksperimen digunakan dalam penelitian ini dengan jenis One Group PretestPostest Design, di mana hanya terdapat satu kelas sebagai subjek penelitian dengan jumlah 20 orang anak didik sehingga sampel tidak dipilih secara random (Sugiyono, 2008:110). Metode bermain peran bertindak sebagai variabel bebas dan kemampuan bahasa ekspresif sebagai variabel terikat. Data diperoleh di lapangan melalui tes (tes awal dan tes akhir), observasi, dan dokumentasi. Kemudian data dianalisis dengan menggunakan statistik deskriptif dan inferensial. Analisis statistik deskriptif dilakukan untuk mendeskripsikan atau menggambarkan pelaksanaan metode bermain peran serta kemampuan bahasa ekspresif pada anak. Sedangkan analisis statistik inferensial digunakan untuk melakukan uji hipotesis tentang pengaruh bermain peran terhadap kemampuan bahasa ekspresif anak dengan menggunakan statistik inferensial uji Wilcoxon.

\section{HASIL DAN PEMBAHASAN}

Sebagaimana yang telah diuraikan pada bagian pendahuluan, yang menjelaskan bahwa tujuan penelitian ini adalah untuk mengetahui gambaran penggunaan metode bermain peran dan gambaran kemampuan komunikasi anak, selain itu juga untuk menguji apakah terdapat pengaruh penggunaan metode bermain peran terhadap kemampuan bahasa ekspresif anak. Pada gambaran penggunaan metode bermain peran ditemukan anak tampak bersemangat mengikuti proses tersebut walaupun pada awal pengenalan metode anak terlihat sangat canggung. Rasa penasaran anak pada karakter/ tokoh yang diperankan membuat anak menyukai metode ini sehingga pada gambaran kemampuan komunikasi (bahasa ekspresif) terlihat mengalami peningkatan secara signifikan. Data tersebut kemudian diolah dengan menggunakan uji Wilcoxon yang pengambilan keputusannya ditentukan dengan membandingkan statistik hitung dengan statistik tabel. Maka, diperoleh nilai $t_{\text {hitung }} \geq$ $t_{\text {tabel }}$ sehingga keputusannya terdapat pengaruh metode bermain peran terhadap kemampuan komunikasi (bahasa ekspresif) anak di TK.

Dari hasil penelitian yang dilakukan diperoleh peningkatan yang signifikan dari sebelum perlakuan dan setelah perlakuan, disebabkan metode bermain peran memberikan pengalaman baru kepada anak didik yang dilakukan secara aplikatif sehingga anak didik dapat berinteraksi dengan temanteman mereka secara langsung. Melalui interaksi tersebut anak melakukan kegiatan berbicara dan mendengarkan sehingga memungkinkan anak akan mendapatkan katakata baru, menggabungkan kata-kata baru serta memberikan pernyataan dan pertanyaan. Seperti yang diungkapkan oleh Moeslichatoen (2004:19) bahwa, "pengucapan merupakan faktor penting dalam berbicara dan pemahaman". Selanjutnya Moeslichatoen menambahkan bahwa, "anak juga akan mengembangkan berbicara jika ia mempelajari kosa kata yaitu menguasai nama benda, mempunyai ide, melaksanakan tindakan".

Dalam kegiatan bermain peran terdapat beberapa aktifitas yang dapat meningkatkan kemampuan aspek bahasa ekspresif anak, yaitu: 
a. Interaksi, dalam hal ini anak anak diarahkan untuk melakukan proses interaksi sehingga anak akan memperoleh kosa kata baru yang bermanfaat dalam kegiatan berbahasa lisan anak seperti yang diungkapkan oleh Suhartono (2005:123) bahwa, "memiliki perbendaharaan kata yang cukup diperlukan untuk berkomunikasi sehari-hari". Selain itu, berkenaan dengan proses interaksi yang dilakukan anak dalam kegiatan bermain peran, Dhieni (2008:3.5) mengungkapkan bahwa, "perkembangan bicara anak terjadi ketika anak dapat berinteraksi dengan temannya atau lingkungannya".

b. Imajinasi, merupakan salah satu dari kelebihan dalam kegiatan bermain peran. Anak tidak harus melakukan kegiatan menghafal kata-kata sebagaimana bentuk dari pelaksanaan pembelajaran konvensional. Metode bermain peran mengajarkan kepada anak untuk berimajinasi dalam memerankan peran sehingga anak dapat mengungkapkan ide, sebagaimana yang diungkapkan oleh Tony Buzan (dalam Sajawandi, 2008:179) bahwa untuk mengingatkan seseorang pada suatu hal perlu dibentuk imajinasi ataupun isyarat tentang sesuatu tersebut. Anak yang memiliki imajinasi dan penghayatan yang tinggi akan lebih mudah memahami topik atau alur cerita. Selain itu, metode bermain peran yang dilaksanakan dengan suasana yang menyenangkan bagi anak dan anak dapat menikmati kegiatan tersebut sehingga secara tidak sadar menemukan kata-kata baru, menghapalkannya serta menggunakannya maka akan melekat kuat dalam ingatan anak sebagaimana yang selalu diungkapkan oleh para ahli bahwa anak usia dini akan lebih cepat mengingat sesuatu yang sederhana dan tidak rumit.

c. Dapat memupuk rasa percaya diri. Walaupun dalam meningkatkan keberanian dan rasa percaya diri kepada anak bukanlah hal yang mudah. Melalui kegiatan bermain peran, keberanian dan rasa percaya diri anak dapat dipupuk apabila kegiatan ini dilakukan secara berulang-ulang tidak hanya dengan sekali bermain ataupun sekali pertemuan saja. Dengan meningkatnya keberanian dan rasa percaya diri anak, akan dapat memberikan pengaruh positif terhadap kelancaran anak dalam berbicara.

\section{KESIMPULAN}

Berdasarkan hasil analisis data, maka dapat disimpulkan bahwa:

Adanya peningkatan yang signifikan antara kemampuan bahasa ekspresif anak didik sebelum diberi perlakuan (tes awal) dan setelah diberi perlakuan (tes akhir) memberikan indikasi bahwa melalui metode bermain. Dalam penerapan metode bermain peran yang dilaksanakan sebanyak delapan kali pertemuan menunjukkan peningkatan mulai terjadi pada pertemuan keempat dan semakin baik hingga pertemuan kedelapan.

Dari hasil uji hipotesis diperoleh nilai $\mathrm{T}$ hitung lebih kecil dari nilai $\mathrm{T}$ tabel dengan demikian Ho ditolak. Artinya terdapat pengaruh metode bermain peran terhadap kemampuan bahasa ekspresif anak TK.

\section{DAFTAR RUJUKAN}

Departemen Pendidikan Nasional. 2005. Pedoman Pembelajaran Di Taman Kanak-kanak. Jakarta: Direktorat Jendral Manajemen Pendidikan Dasar dan Menengah.

Dhieni, N. dkk. 2008. Metode Pengembangan Bahasa. Jakarta: Universitas Terbuka.

Hurlock, B.E. 1978. Perkembangan Anak (Edisi Keenam). Terjemahan oleh Meitasari Tjandrasa. Jakarta: Erlangga.

Hartati, S. 2005. Perkembangan Belajar Pada Anak Usia Dini. Jakarta: Departemen Pendidikan Nasional, Direktorat Jenderal Pendidikan Tinggi, Direktorat Pembinaan Pendidikan Tenaga Kependidikan dan Ketenagaan Perguruan Tinggi.

Moeslichatoen. 2004. Metode Pengajaran di Taman Kanak-Kanak. Jakarta: Rineka cipta.

Mutiah. 2010. Psikologi Bermian Anak Usia Dini. Kencana Prenada Media Group. Jakarta.

Rakhmat, J. 2009. Psikologi Komunikasi. Bandung: Remaja Rosdakarya.

Sajawandi. 2010. Dampak Aplikasi Model Pembelajaran Rumah Qur'ani. 
Pembelajar: Jurnal Ilmu Pendidikan, Keguruan, dan Pembelajaran 1 (2) 2017

Bandung: Universitas Pendidikan Bandung.

Santrock, W.J. 2007. Perkembangan Anak. Terjemahan Mila Rachmawati dan dan Anna Kuswanti edisi ke-11. Jakarta: Erlangga.

Sugiyono. 2008. Penelitian Pendidikan Pendekatan Kuantitatif, Kualitatif, dan $R \& D$. Bandung: Alfabeta.
Suhartono. 2005. Pengembangan Keterampilan Bicara Anak Usia Dini. Jakarta: Depdiknas.

Syaiful B.D. 2004. Pola Komunikasi Orang Tua \& Anak dalam Keluarga. Jakarta: Rineka Cipta. 